\title{
Maciej Mataczyński (ed.), The Takeover of Public Companies as a Mode of Exercising EU Treaty Freedoms
}

\author{
Peter Lang GmbH, Frankfurt-on-Main 2017, 199 pp. \\ ISBN 978-3-631-67099-6
}

\section{Krzysztof Oplustil ${ }^{1}$}

Published online: 12 November 2018

(c) The Author(s) 2018

The reviewed volume is the outcome of joint work by an international research team financed with the funds awarded by the Polish National Science Centre. The papers included in the book deal with the relationship between freedoms enshrined in the Treaty on the Functioning of the European Union (TFEU) and takeovers of public companies. All the texts have been written in English by Polish and German scholars representing the current referred to as the doctrine of the young generation. The reviewed volume consists of a total of eight studies devoted to various aspects of the free movement of capital and takeovers of companies in the EU, such as the admissible restrictions of this freedom, the horizontal effect of treaty freedoms and in particular the free movement of capital, the duties of board members in the context of a takeover attempt and the use of preventive anti-takeover measures and, finally, the issue of possible Brexit's influence on the European takeover law.

The topics discussed in the volume are pertinent and important both from academic and practical perspective. Takeover law has been harmonized by EU Directive 2004/25/EU on takeover bids ${ }^{1}$ (also known as the Thirteenth Directive), whose harmonising effect, especially as regards the admissibility of the so-called preventive and reactive defences against takeovers, might be challenged. ${ }^{2}$ The Court of Justice (CJEU) case law on the compliance of the 'golden shares' with the treaty freedoms of movement of capital and establishment is yet another key issue in this field. However, studies included in the reviewed volume do not focus on EU takeover law

\footnotetext{
1 Directive 2004/25/EC of the European Parliament and of the Council of 21 April 2004 on takeover bids [2004] OJ L142/12.

${ }^{2}$ See, e.g., Clerc and Demarigny (2012), pp 122 et seq.

Krzysztof Oplustil

krzysztof.oplustil@uj.edu.pl

1 Chair of Economic Policy of the Faculty of Law and Administration, Jagiellonian University, Kraków, Poland
} 
exclusively, and take account of the national context (mostly Polish and German regulations governing capital markets), as well as economic and institutional factors that influence the market of mergers and acquisitions (M\&A). In consequence, the scope of issues discussed in the volume is broader than suggested by the title.

Based on the perspective assumed by the authors analysing the issue of company takeovers, papers included in the volume could be classified into three categories (groups). The first category comprises studies that focus on the economic and institutional aspects of such transactions and provide a framework that 'binds' the volume as such. The group includes the opening article by Szyszko and the final one co-authored by Gołecki and Mataczyński. The first study (pp 9-28) lays down the economic background for strictly legal studies which follow. In his paper Szyszko introduces a typology of mergers and acquisitions, discusses their rationale and underlying motives, and presents the perspectives of shareholders and management, as well as psychological aspects of decision-making in this context. Subsequently, the author attempts to answer the question about the economic value (if any) of takeovers for shareholders in the short- and long-term perspective. As the author is right to note, there is no clear-cut answer to this question, while any attempts at generalisations are bound to be unsuccessful. Meanwhile, the paper by Gołecki and Mataczyński (pp 175-198) focuses on the economic-institutional and legal aspects of the so-called 'national champions'-companies classified as having major ('strategic') importance for public and national interest. The starting point for the discussion is the authors' claim (unfortunately unsupported by any empirical data) that companies influenced by the state are currently playing a major role in the economies of EU Member States. The authors analyse the mechanism to which the state could resort in order to exert influence on companies, pointing out related threats resulting from additional agency relationships that go beyond the traditional agency conflict between (dispersed) shareholders and the management. As the authors are right to conclude, while typical public companies are struggling with the problem of 'no owner, no principal' who would exercise effective control of the agentsmanagers, in the economic model that assumes the dominant (or at least significant) involvement of the state we are facing the problem of multiple principals representing various levels of state administration and a variety of factions within the governing party. Current Polish experiences related to 'national champions' confirm this to be the case. In conclusions to their paper the authors present a strong thesis (though, yet again, unfortunately unsupported by empirical research or a reference to such research) that the multiplicity of agency problems and the 'patronage' that occurs in companies controlled by the state unavoidably leads to the lack of effectiveness and underperformance. The analysis, mostly of economic-institutional nature, is based on vast (mostly common law) literature. A certain flaw of the paper is the fact that its authors fail to refer to (or at least mention) the OECD Guidelines on Corporate Governance of State-Owned Enterprises, ${ }^{3}$ which outline a set of universal governance standards applicable to states that act as owners of enterprises.

\footnotetext{
${ }^{3}$ OECD Guidelines on Corporate Governance of State-Owned Enterprises, 2015 edition (OECD Publishing, Paris).
} 
The second group of papers focuses on EU primary law, including the free movement of capital, and the related CJEU judgments. The article by Majkowska-Szulc (pp 29-50) analyses the Court's case law on the freedom of establishment, focusing on Court's opinions on admissible restrictions on that freedom (and the differentiation between them) in trade within the European Union and between EU Member States and third states. The author is right to claim that the case law supports divergent interpretations on the admissible extent of such restrictions with respect to third parties, which she justifies by the differences in the legal context and the need to protect public interest in Member States. Taborowski's study (pp 51-84) is dedicated to the so-called horizontal effect of (the application of) freedoms enshrined in the treaty. The author acknowledges the inconsistent approach of the Court to the possible existence of horizontal effect of a variety of treaty freedoms, admitting, under certain conditions, horizontal application of primary legislation in the case of the freedom of movement of services and freedom of establishment. However, as of today, CJEU has not had a chance to make any pronouncements with respect to the horizontal effect of the freedom of movement of capital. In his subsequent paper included in the volume under review, Mataczyński firmly rejects the possibility of horizontal application of that freedom, presenting a vast and convincing argumentation to support his view (pp 85-100). One should agree with the author that effective EU law gives no grounds for CJEU to review national corporate law and the resultant internal corporate legislation, which does not award any preference to public law entities, from the perspective of its potential 'discouraging effect' on investors from other states.

The third category of papers consists of studies on national takeover law in the context of EU secondary law, i.e. Directive 2004/25/EC. Tomasz Sójka (pp 101-116) scrutinises managerial duties in a company which has become a target of a tender offer aimed at takeover in the context of Polish law. The author is right to point out the permissive nature of legal regulations when it comes to the measures that the management board can resort to in order to frustrate a so-called hostile takeover, emphasizing that neither Polish case law nor legal sciences have developed any standards of conduct which the management should obey when a hostile takeover is looming over the company. In the subsequent paper (pp 117-132) the same author discusses the issue of preventive defences in the context of Polish law. A starting point for the discussion is a statement that, like in the case of the neutrality principle laid down in the Thirteenth Directive, the Polish legislator has exercised its 'opt-out' option also with respect to the breakthrough rule. As a result, Polish law allows for an entire range of 'corporate enhancement mechanisms' (CEMs) aimed at discouraging any hostile takeover attempts. The author discusses the most frequently used mechanisms, voicing particular criticism with respect to the voting cap, with a selective exemption of a specific shareholder-State Treasury-from this rule. As the author is right to add, the current use of this institution has resulted in a distortion of its original function, namely the protection of shareholders against one shareholder gaining dominance. Currently, this institution is being used to petrify the control exercised by the State Treasury, despite its minority interest in the company. There are major doubts as to the compliance of voting caps in internal corporate legislation with the principle of proportionality of capital involvement and shareholders' rights. 
It is unfortunate that the author did not attempt an assessment of compliance of selective voting restrictions awarding preference to the State Treasury with the freedom of movement of capital in the context of CJEU case law on 'golden shares'.

Also the paper by Möslein (pp 133-174) falls into the category of studies focusing on national law. It analyses the scope, structure and basic rules laid down in the German Act on the acquisition of securities and takeovers (WpÜG) of 2001 in comparison to British regulations. The author presents an interesting and bold claim that the looming Brexit can eventually lead to the approximation and actual harmonisation of national regulations on takeovers in EU Member States.

To sum up, the reviewed volume is a valuable contribution whose unquestionable strength is the fact that it approaches the issue of takeovers of public companies chiefly from the perspective of Poland - a state that has joined the EU only recently. There has been a deficit of studies on Polish corporate and capital market law in the English language. The volume will, at least partially, bridge this gap. What is more, the variety of perspectives from which takeovers are analysed adds up to the interdisciplinary, comparative nature of this work. It is aimed at both legal scholars and practicing lawyers who apply EU and national capital markets law.

Open Access This article is distributed under the terms of the Creative Commons Attribution 4.0 International License (http://creativecommons.org/licenses/by/4.0/), which permits unrestricted use, distribution, and reproduction in any medium, provided you give appropriate credit to the original author(s) and the source, provide a link to the Creative Commons license, and indicate if changes were made.

\section{Reference}

Clerc Ch, Demarigny F (2012) A legal and economic assessment of European takeover regulation. Marccus Partners, The Mazars Group. https://www.ceps.eu/system/files/Takeover\%20Bids\%20Directiv e\%20book\%20-\%20Final.pdf. Accessed 28 September 2018

\footnotetext{
${ }^{4}$ See, in particular, Case C-543/08 Commission v. Portugal (Golden shares) [2010] ECR I-11241 and Case C-112/05 Commission v. Germany [2007] ECR I-8995.
} 